\title{
Brand Endorsement by Celebrity in Thailand: 7Ps of Marketing Mix and the Impact of Brand Alliance
}

\author{
Whachiraporn Boonpradub and Pusanisa Thechatakerng
}

\begin{abstract}
Thailand, a developing country where textile fashion business is supported from the government and is growing fast which is interesting in brand alliance education. While there are more retails of new face fashion designers have been building their own brands, to crack market is not easy. Brand alliance then has been seen as an alternative way to accelerate market. This paper aims to discover the impact of celeb brand endorsement towards consumer, the 7P's of marketing mix and the experience of consumers in buying brand endorsement by celebrity products, especially the celebrity as the designer in textile fashion products. This exploratory research based on responses from 400 customers in a store where is the pioneer of "celebrity designer and the brand endorser" in Thailand. The result implies that customers give credit to celeb and accept as the brand's designer team to design the products. Moreover, the 7Ps of marketing mix play the affecting role toward consumers in buying endorsed brand product by celeb, especially process factor while physical evidence play less important factor. Besides, the experiences of consuming the celeb endorsed brand products are excellent. Most respondents are pleased with the products and their satisfaction is more than expectation.
\end{abstract}

Index Terms-Brand endorsement, brand alliance, consumer, celebrity, 7Ps of marketing mix, Thailand.

\section{INTRODUCTION}

In Thailand, industries which have been tough stroke by the economic crisis are building materials, motor vehicles and transport equipment. In contrast, petrochemicals, and textiles industries continued to rise in spite of the economic crisis [1]. Textile industry is a term used for industries primarily concerned with the design or manufacture of clothing as well as the distribution and use of textiles including fashion business [2]. Today's fashion has changed rapidly. Many garments firms have been establishing while many garments firms have gone. Most firms must compete with the economic crisis and new trends that has been changed every single day. Some changes have occurred to many societies. For example, from agricultural society to industrial society, from world's food production country to the world's fashion production country [3]. Strategic alliance has been seen as an important tool to accelerate market [4]. Brand Alliance is as Brand endorsement.

Brands endorsement, a type of strategic alliance by celebrities has been using over the past years as another

Manuscript received May 7, 2014; revised August 28, 2014.

Whachiraporn Boonpradub is with School of Design, Northumbria University, Newcastle, UK (e-mail: whachiraporn@yahoo.com).

Pusanisa Thechatakerng is with Faculty of Business Administration, Maejo University, Thailand (e-mail: thepusanisa@yahoo.com). popular marketing tool. Celebrity endorsements are encouraged by excellent of the following motives: instant brand awareness and remember, celebrity values identify and energize the brand image, celebrities add new dimensions to the brand image, instant trustworthiness or target public relation coverage, and persuasive clients [5]. Many brands in the world have been using this strategy for many years. For example, in 2013, there were brand endorsement by celeb such as Gucci loafers from Grace Kelly's granddaughter, A Louis Vuitton tote from Angelina Jolie, An H. Stern ring from Katie Holmes or a Burberry trench from Romeo Beckham, and a bottle of Chanel No. 5 from Brad Pit [6]. Even in 2007, Topshop collaborated with Kate Moss who is the second highest paid model in the world (forbes.com). While in Thailand, brand which is endorsed by celebrity is still a new marketing strategy, especially celebrities as designers. CPS CHAPS, a famous authentic Thai brand in Thailand has used the brand alliance strategy which the brand is endorsed by a celebrity named Chermarn Bunyasak or "Ploy". CPS is the first brand in Thailand that uses this kind of strategy by taking Chermarn to join the designer team. Chermarn has played an important role as the representative of today's trendy women who has an individual personality and clear style like the brand image. Chermarn is a Thai actress who is smart, gorgeous, sexy and charming which answer the brand concept perfectly ${ }^{1}$.

\section{CPS: CHAPS}

CPS: CHAPS was established under Jaspal group of company. Jaspal Company Limited is a leading fashion retail company engaging in designing, manufacturing and marketing of several leading clothing and accessories brands. The company's success and growth come from the company's own brands including JASPAL, CPS: CHAPS, CC-OO and LYN as well as imported brands including FOOTWORK, FOOTWORK NOIR, VIA UNO, SONORA and etc. While keeping up a strong brand image, the company has entered the regional market by franchising the brands outlet throughout the Asia market, as well as other major cities in the world. There are over 900 professional employees working in teams dedicated to each product line and network of 102 retail shops in major department stores ${ }^{2}$.

As this brands endorsed by celebrities strategy is fresh in Thailand, then the research in this area is still limited. So, the study of brands endorsement by celebrity in Thailand is interesting. This paper aims to discover the impact of celeb brand endorsement towards consumers, the 7P's of

\footnotetext{
${ }^{1}$ Information taken from CPS official website at www.chapsclothing.com ${ }^{2}$ Information taken from Jaspal \& Sons Company Limited
} 
marketing mix and the experience of consumers in buying brand endorsement by celebrity products. It would be advantages for Thai businesses in the area of textile fashion to analyze and find the right marketing strategies for their brands, especially to enter local markets. Then this paper tries to enhance the knowledge in this area. Moreover, this paper tries to answer 4 questions: i) What the customers' characteristics in buying brand endorsement by the celebrity's product are? ii) How is the impact of celeb brand endorsement towards consumers? iii) Do they make the right match between the endorser and the brand? iv) Do 7Ps of marketing factors affect consumer buying celeb allied brand products and which factor most affect consumers? v) How are their experiences with brand endorsement by the celebrity's product?

\section{LITERATURE REVIEW}

\section{A. Brand Alliance as Brand Endorsement}

Brand alliances are created for an assortment of reasons with to provide as marketplace signals which are the primary brand and its brand ally together can indicate value to the marketplace [7]. The brand alliances may improve the image of the primary brand and signal better product quality, may have more effect on common brands activated the transfer of consumer affect from a high-quality to a low quality brand, may influence quality perceptions of unnoticed product characteristic of a partner brand, and may increase the attitudes toward the associated brands [8], [9].

Brand endorsement by celebrity is also a kind of brand alliance which is the research concerned with the celebrity endorsement has been [7], [11]-[16]. Celebrity endorsements have numerous benefits, like building trustworthiness and getting awareness of the public, which can explain into upper sales. Mainly, celebrity endorsements are being chosen for almost every kind of products. But, risks have also been related with celebrity endorsements. The brand will collapse as quickly as it moved up in the market even with famous celebrities endorsing them [5], [8], [17]. To analyze the major factors that are having maximum impacts of successful endorsement, the followings are found out; Appeal, Notice, Trend setting, Influence, Trust, Endorsement, Aspiration and Awareness [18].

\section{B. 7Ps of Marketing Mix}

MacCarthy developed and polished the concept of marketing mix of Vignaly \& Davies to be theory to what is normally recognized nowadays as the 4Ps Product, Price, Place, and Promotion [19], [20]. But for the business concerned with service, 4Ps are not enough. An extended of the 4Ps was formed by Booms and Bitner which is useful for service business. The additional 3Ps are People, Process, and Physical Evidence [21], [22]. Product, for many people a product is only the touchable, physical unit that they may be buying or selling, the product more complex. The product includes Brand, Quality, and Style. The variables selected as most crucial determinants of company control over the element "Product" were "Quality" and "Branding" [12]. Product (goods and services) frequently are the crucial point of positioning strategy, mainly when companies or business units adopt organizational approaches highlighted product or brand management [23]. Price plays an important role in positioning a product or service. Customer reaction to alternative prices, the cost of the product, the prices of the competition and various legal and ethical factors establish the extent of flexibility management has in setting prices. Price is also used on other marketing mix components. Place or distribution channel influences buyer's positioning of the brand. Decisions that need to be made include the type of channel organization to use, the extent of channel management perform by the firm, and the intensity of distribution appropriate for the product or service. Promotion consists of publicity, sales promotion, the sales force, direct marketing, and public relations help the organization to communicate with its customers, value-chain partners, the public, and other target audiences. These activities make up the promotion strategy, which performs an essential role in communicating the positioning strategy to buyers and other relevant influences. Promotion informs, reminds, and persuades buyers and others who influence the purchasing process. People that are directly or indirectly concerned in the use of a service are an important part of the Extended Marketing Mix. Knowledge workers, employees, management and consumers often add significant value to the total product or service offering. Process; Procedure, mechanisms and flow of activities by which services are consumed(customer management processes) are an essential element of the marketing strategy. Physical Evidence is the ability and environment in which the service is delivered, both touchable products that help to communicate and perform the service, and the intangible experience of existing customers and the ability of the business to relay that customer satisfaction to potential customers [23].

\section{Personal Factors}

A consumer decisions are also influenced by personal characteristics. These include the buyer's age and stage in the life cycle, occupation, economic, circumstances, life style, and personality and self-concept [24]. Age and stage in the life cycle - People buy different goods and services over the lifetime.. Taste in clothes, furniture, and recreation is also age related [25]. Occupation and economic circumstances - Marketers try to identify the occupational groups that have above-averages interest in their products and services. A company can even tailor its products for certain occupational groups [24]. Lifestyles- A lifestyle is a person's pattern of living in the world as expressed in activities, interests, and opinions. Lifestyle portrays the "whole person" interacting with his or her environment. Marketer may then aim the brand more clearly at the achiever lifestyle [26]. Personality and Self-concept Personality is often described in terms of such traits as selfconfidence, dominance, autonomy, deference, sociability, defensiveness, and adaptability [27]. Personality can be a useful variable in analyzing consumer brand choices [28]. Income - the fashion shopping behavior of consumers is be influenced by their salary and price [29]. Education education affects the taste of the target group in deciding to buy the products [30].

\section{The Methodology}

Due to there is limited research concerned with this topic 
in Thailand, the exploratory research need to be investigated for required information about the brand endorsement by celebrity in Thailand especially the brand CPS:CHAPS. So, we are not formulated the hypothesis. CPS+PLOY under the brand CPS: CHAPS has focused on the women in the age of 17-30 only ${ }^{3}$. This paper, the questionnaires were handed out to the females aged 17-30 years in Chiang Mai who visited the CPS: CHAPS store during the survey period. 32,160 customers are the target group of CPS+PLOY ${ }^{4}$. Followed the Krejcie and Morgan sampling size, then, 379 would be selected. However, to reduce the error that might happen from the surveying, 400 respondents are used as sample by convenience sampling [31].

Questionnaire used to collect the information related to the characteristics of target sample, general information about brand endorsement by celeb, 7Ps of marketing mix and experience of consumer with celeb endorsed brand product. The variables associated to affect factors deliberated in the Likert scale of five positions. Basically, each respondent was asked to specify the level of affect to which $\mathrm{s} /$ he preferred with the given statement, such that $1=$ Not very affect and $5=$ Most affect.

\section{THE FINDINGS}

For this part, the result of the study is divided into four parts. The first part is about the characteristic of respondents, which is explained about education, their income, status of the respondents, and the type of respondents in fashion interest. The second part is focused on brand endorsement by celebrity. The third part, 7Ps of marketing mix is identified. Last part is clarified about the experiences of respondents in celeb brand alliance product purchase.

\section{A. The Characteristic of the Respondents}

Education, income and status of the respondents are the variables explaining the personality of the target group.

\section{1) Education and income}

The education affects the taste of the target group in deciding to buy the products [30]. In this study I classified education into 3 categories; college, undergraduate, graduate. Table I shows that 304 of respondents were in university level. The study identifies that CPS: CHAPS was popular in university level. Income also plays an important role in customer classification, the more people have higher income, and the more they have got purchase power. While the people who earn less, they are not able to buy the premium products because of their financial limitation [27]. The fashion shopping behavior is obviously influences by price [32]. The result identifies that most CPS: CHAPS customers are in university level and have income between 10,000-15,000 THB and 15,000-25,000 THB per month.

\section{2) Status and income}

The status is another significant variable that influences

\footnotetext{
${ }^{3}$ Information taken from Jaspal \& Sons Co. Ltd. that the brand CPS+PLOY(CPS:CHAPS) is affiliated.

${ }^{4} 32,160$ is the amount of customers per year, the information interviewed from the CPS:CHAPS Chiang Mai branch's manager in July 2008)
}

people in purchasing. Because of the people who have got families, they have got others expenses such as the education for their children or others facilities for their families. Thus, they also need to limit themselves in purchasing [33]. Majority of respondents is single with between 5,000-25,000THB monthly. However, the largest number of respondent has had 10,000-15,000 THB.

\section{3) Type of the respondent}

The result implies the fashion trend reaction of the respondents that almost the half of respondents prefers to be the most fashionable and always keep up with fashion trends. Moreover, almost the same amount of them, 36\% prefer to be the observer and wait until the trends become popular enough and worth to purchase. However some of them are the fashion observers who keep up with the fashion trends sometimes.

\section{B. Brand Endorsement by Celebrity}

In capturing the idea of the impact of celeb brand endorsement towards consumer, the following factors are used: customer's perceived brand endorsement product, the credibility and acceptability of the endorser by customer, awareness of brand endorsement by celeb, celeb's Characteristics toward customers, the reflection of celebrity endorsement on brands. All information above could help to understand some significant information from consumers for analyzing the best way to generate the strategies appropriate in business.

\section{1) Customer's perceived brand endorsement product}

Table I indicates that 240 respondents out of 400 have seen the allied product but not all of them have bought the products. Slightly more than a half of products noticed were purchased. 136 out of 400 respondents have purchased the allied products.

TABLE I: CUSTOMER's PERCEIVED BRAND ENDORSEMENT PRODUCT

\begin{tabular}{|l|l|l|l|}
\hline \multicolumn{2}{|l|}{ Allied Products Noticed } & \multicolumn{2}{l|}{ Allied Products Purchased } \\
\hline Yes & No & Yes & No \\
\hline $240(60 \%)$ & $160(40 \%)$ & $136(57 \%)$ & $2 \%)$ \\
\hline
\end{tabular}

\section{2) Credibility and acceptability of the endorser by customer}

TABLE II: CREDIBILITY AND ACCEPTABILITY OF THE ENDORSER BY

\begin{tabular}{|l|c|c|c|c|c|c|}
\hline \multicolumn{1}{|c|}{ Brand alliance } & \multicolumn{3}{|c|}{ Amount } & & \multicolumn{2}{c|}{ Total } \\
\cline { 2 - 7 } & & $\mathrm{N}$ & $\%$ & & $\mathrm{~N}$ & $\%$ \\
\hline $\begin{array}{l}\text { CPS +Celebrity } \\
\text { The brand use the } \\
\text { celebrity's name } \\
\text { to ally the name } \\
\text { of the brand and } \\
\text { trust }\end{array}$ & Yes & 240 & 60 & & 400 & 100 \\
customers by & 160 & 40 & & & \\
\hline $\begin{array}{l}\text { Celebrity has } \\
\text { designed for the } \\
\text { brand's products } \\
\text { and accept by } \\
\text { customers }\end{array}$ & Yes & 208 & 52 & & \multirow{2}{*}{240} & 100 \\
\cline { 2 - 6 } & & 32 & 8 & & & \\
\hline
\end{tabular}

Table II points out that $60 \%$ of respondents know that the brand is endorsed by the celebrity and trust her. In the 
amount of 60 percent or 240 respondents, almost every respondent knows that the celebrity has endorsed the brand by joining the brand's designer team to design the products and accepts the celeb. However, almost the half of respondents still lack of the perception and information about the allied brand. So the information below can indicate that the brand endorsement by celebrity strategy at least create the attention among the existed customers.

\section{3) Awareness of brand endorsement by celeb}

The respondents were asked to respond about the channel of their awareness regarding to brand endorsement by celeb. They were allowed to respond more than one resource. The results indicate in Fig. 1 that $28 \%$ of customers aware their brand alliance via magazine, $19 \%$ via entertainment news, in addition $14 \%$ via friends and retail's staffs, respectively.

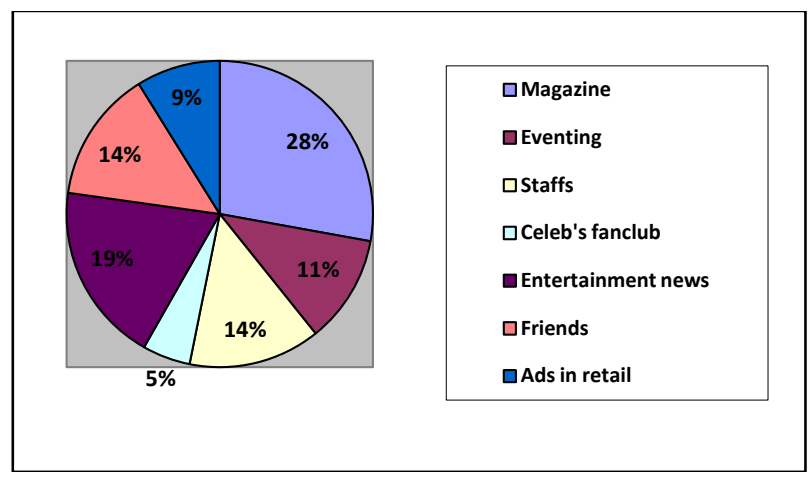

Fig. 1. Awareness of brand endorsement by celeb.

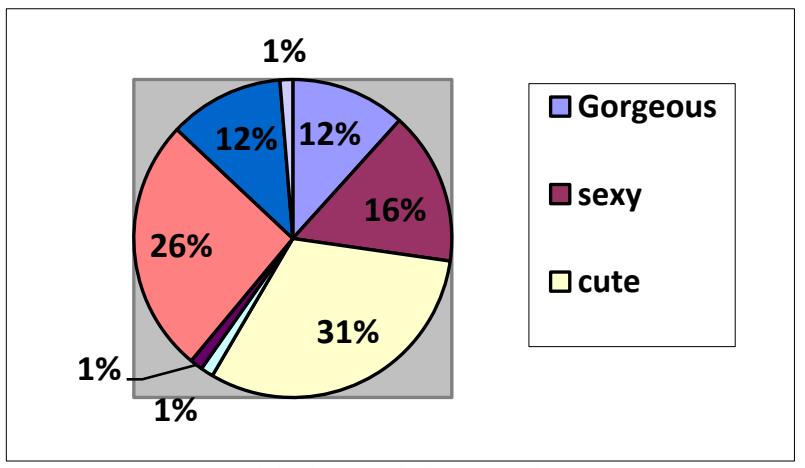

Fig. 2. Celeb characteristics toward customers.

\section{4) Celeb's characteristics toward customers}

In this point, Celeb's characteristics were pointed out by target group and also they were asked whether allied brand image could be reflected by celeb. The celeb's characteristic can answer the brand image fit to the endorser. Obviously, Most have positive opinion; which are cute, trendy, and sexy to the celeb and their perception is just the same as mentioned above the brand's positioning and image needed. In sum, the brand has used the right endorser to reflect the characters needed of the brand which is able to answer the target taste of consuming the products [34].

\section{5) The reflection of celebrity endorsement on brands}

TABLE III: ALLIED BRAND REFLECTION

\begin{tabular}{|l|c|c|}
\hline Brand Reflection by Celeb & $\mathrm{N}$ & $\%$ \\
\hline Agree & 288 & 72 \\
\hline Disagree & 112 & 28 \\
\hline
\end{tabular}

Most respondents which are $72 \%$ believe that the celeb is able to reflect the brand image properly while only $28 \%$ of them disagree (Table III). The allied brand match makes the right image towards customer.

\section{The 7Ps of Marketing Mix Factors}

The marketing factors provide the information about the factors that affect the consumers in buying the celeb endorsed brand which consist of Product Factor, Price, Channel, and Promotion, Process, People and Physical Evidence. In this part, respondents were asked to rate the factors affect customer in purchasing allied brand by using 5 likert scale which $1=$ Least affect and 5=Most affect. The items measuring marketing factors presented a Cronbach Alpha equal to 0.527 . Nunnally referred that the Cronbach Alpha minimum acceptable equal 5 for exploratory research [35].

\section{1) Product factor}

The descriptive statistic shows that the consumers pay attention to brand and design in the high level (4.22). Table IV points out that the respondents have emphasized on the brand itself and the design (4.22) more than the quality (4.04).

TABLE IV: PRODUCT FACTOR

\begin{tabular}{|l|c|c|c|c|c|}
\hline & $\mathrm{N}$ & $\mathrm{Min}$ & $\mathrm{Max}$ & Mean & SD. \\
\hline Factor & 400 & 3 & 5 & 4.22 & .783 \\
\hline Designd name & 400 & 3 & 5 & 4.22 & .808 \\
\hline Quality & 400 & 3 & 5 & 4.04 & .775 \\
\hline
\end{tabular}

\section{2) Price, channel, and promotion}

The respondents are very much attracted by price (4.14). The respondents scale only 3 to 5 and most attracted by the promotions. While promotion (4.24) and price (4.14) are very important factors causing the buying endorsed brand product, channelis another factor that has less strong power for customers. This indicated that when people are attracted by the promotion and price, they commonly buy without thinking about the convenience channel to buy celeb endorsed brand product as the mean shows of 3.72 with the minimum of 3 and maximum of 5. Table $\mathrm{V}$ shows that respondents are affected by promotion and price, while they are not as much of affected by the location or channel of distribution.

TABLE V: PROMOTION, PRICE AND CHANNEL FACTORS

\begin{tabular}{|l|c|c|c|c|c|}
\hline Factors & $\mathrm{N}$ & Min & Max & Mean & SD. \\
\hline Promotion & 400 & 3 & 5 & 4.24 & .764 \\
\hline Price & 400 & 3 & 5 & 4.14 & .850 \\
\hline Channel & 400 & 3 & 5 & 3.72 & .695 \\
\hline
\end{tabular}

\section{3) Process}

TABLE VI: PROCESS FACTOR
\begin{tabular}{|l|c|c|c|c|c|}
\hline Process & N & Min. & Max. & Mean & SD. \\
\hline Queuing system & 400 & 3 & 5 & 4.58 & .696 \\
\hline Cash desk location & 400 & 3 & 5 & 4.22 & .757 \\
\hline After sale service & 400 & 3 & 5 & 4.72 & .450 \\
\hline
\end{tabular}

The most influence process affect respondents in purchase is after sale service (4.72) such as return or refund policy 
following with queuing system (4.58) and the location of the cash desk (4.22). Table VI indicates that most respondents are drawn by after sale service process such as refund policy or return policy with few differences of other things.

\section{4) People and physical evidence}

The results show that decoration (4.36) in the retail shop has a very strong affect in buying allied product and follow up with the good service from staffs (3.52) while the music (3.26) and the temperature (3.42) in the store are also able to build the customer's happiness while they are looking around in the store. Table VII shows that the store decoration has the strongest power in motivating customer to buy allied product while the music does not have so much power in it. The physical evidence is another significant tool, which fulfills other tools to persuade consumer to purchase the endorsed products by stimulating the need or increasing the happiness.

TABLE VII: PEOPLE AND PHYSICAL EVIDENCE
\begin{tabular}{|l|c|c|c|c|c|}
\hline Factors & N & Min & Max & Mean & SD. \\
\hline Service quality & 400 & 2 & 5 & 3.52 & .986 \\
\hline Decoration & 400 & 3 & 5 & 4.36 & .626 \\
\hline Music & 400 & 2 & 5 & 3.26 & 1.056 \\
\hline Air conditioner & 400 & 2 & 5 & 3.42 & .920 \\
\hline
\end{tabular}

\section{Experience of Consumer to Brand Endorsement by Celebrity}

In this part, respondents were asked to rate their experience about brand alliance product purchase by using 5 likert scale which $1=$ the worst and $5=$ the best. The items measuring experience of customers in buying allied product presented a Cronbach's Alpha equal to 0.885. The experiences of consuming the allied products are excellent. Most respondents are pleased with the allied products they have purchased (4.45) and they think that the products worth to spend the money on (4.68). Moreover, they are satisfied with the endorsed brand products (4.06). They have not expected much for the products but they receive lots of satisfactions after the purchase.Table VIII explains that most respondents have the best general experience. Moreover they absolutely agree toward the worthiness of the product. Furthermore, most of them are very satisfy with the products.

TABLE VIII: THE RESPONDENTS’ EXPERIENCE WITH CELEB ENDORSED

\begin{tabular}{|l|l|l|l|l|l|}
\multicolumn{7}{|c|}{ BRAND PRODUCTS } \\
\hline Satisfaction's level & 4 & \multicolumn{2}{l|}{5} & Mean \\
\hline $\begin{array}{l}\text { Experiences' } \\
\text { description }\end{array}$ & $\mathrm{N}$ & $\%$ & $\mathrm{~N}$ & $\%$ & \\
\hline $\begin{array}{l}\text { General Experience } \\
\text { Worthiness of allied } \\
\text { brand }\end{array}$ & 128 & 32 & 272 & 68 & 4.68 \\
\hline $\begin{array}{l}\text { Satisfaction comparing } \\
\text { with the first thought }\end{array}$ & 272 & 58 & 96 & 24 & 4.06 \\
\hline
\end{tabular}

$\mathrm{N}=$ Number, Mean=most scale that respondent rated on. $1=$ less, $5=$ most

\section{CONCLUSIONS AND DisCUSSIONS}

This paper has reviewed the literatures on the brand alliance which has many forms to choose to use for the business. The brand alliance by using the fame of the endorser is the main idea that this paper is investigated on. In the review, it is noticeable that applying the celebrity as endorser has been very popular and typical strategy used to build the strong brand image. This paper explains that even "the celebrity as the designer" is still very innovative in Thailand especially in the non-capital city like Chiang Mai; people are still very interested in it and response to it very fast. Moreover, the alliance strategy using the fame, the ability and the image of celebrity can convince the consumer in consuming the products as well. Using this strategy, the brand needs to pay attention to 7 Ps of marketing mix toward consumer buying celeb endorsed products. While there are massive competitive brands, immense strategies implemented to strike the competitors. The celebrity strategy may not always increase the selling force but absolutely increase the popularity if the endorser is well matched to reflect the accurate brand image.

The research reveals that 7Ps of marketing mix play the affecting role toward consumers in buying endorsed brand product by celeb, especially process factor while physical evidence play less important factor. Besides, the experiences of consuming the celeb endorsed brand products are excellent. Most respondents are pleased with the products and their satisfaction is more than expectation. Furthermore, the most effective promotional approach is still through the celebrities, most publicity raise the awareness and retain information by using the celebrities as presenters. However some promotional approaches are still ineffective to use in Thailand. Noticeable, all of them are via electronic communication such as telemarketing, online advertisement and email. The case study of the brand evaluated attributes important not only in specific store but also between consumers.

Lukas, Ballester \& Espallar do the survey most took in developed countries [36], [37]. In some researches, the perception of consumers emphasize on the image of the brand and quality [38] while in Thailand, people emphasizes on the design and the brand name of the product more than anything. In developed countries the development of electronic marketing is fast. In contrast, Thai consumers are still be in the initial stag being attracted from those electronic communication, telemarketing or even online advertisement with support the opportunities for gaining more money [17]. In consistent with Elyas \& Mohamed confirm that it is important to notice that this brand alliance could provide it more advantages and benefits in expanding the market of telecommunication and encouraging competition in this field which is an extensive spread of technological development due to the influence of globalization [7].

\section{SUGGESTION AND FutURE RESEARCH}

Due to brand endorsement, especially the celebrity who is more than only normal endorser but being a designer in Thailand is still a new issue, the exploratory research need to be investigated on. The research focused on an authentic Thai brand and Thai celebrity, the comparative research should be studied between Thai brand and brands from other 
countries both developed and developing countries. The financial performance and society reaction are recommended to explore. Competition in fashion retailing is extreme, with image reflected by celeb or presenter is important, the retail resources should be invested.

\section{REFERENCES}

[1] Bangkok Bank. (2002). [Online]. Available: http://www.bangkokbank.com

[2] C. W. Smith, Cotton: Origin, History, Technology and Production, John Wiley \& Sons, 1999.

[3] S. Thechatakerng and J. C. Rialp. (2005). When they go together: alliances implementing by Thai firms. European Academy of Management 2005 (EURAM), Munich, Germany, TUM Business school. [Online]. Available: http://euram2005.wi.tum.de/index.php/Paper323.pdf?page=download Paper_afterconference\&form_id $=323$

[4] S. Thechatakerng, The Implementation of Strategic Alliances by Thai Firms, Universitat Autonoma de Barcelona, p. 2, 2003.

[5] W. Boonpradub, "Brand alliance: The consumer perception and habits toward brand endorsement by celebrity in Thailand," School of Design, Northumbria University, Newcastle, UK, 2009.

[6] T. Guadoin. (2013). The celebrity endorsement game. [Online]. Available: http://www.departures.com/articles/the-celebrityendorsement-game

[7] S. Elyas and Y. Mohamed, "Brand alliance, a strategy to enter new markets and a tool for positioning," Journal of Knowledge Management, Economics and Information Technology, vol. 3, no. 5, 2013.

[8] J.-Y. Suh and S.-B. Park, "Successful brand alliance and its negative spillover effect on a host brand: Test of cognitive responses," Advances in Consumer Research, vol. 36, pp. 243-247, 2009.

[9] Ballester \& Espallardo. (2008). Building online brands through brand alliances in internet. [Online]. Available: http://www.emeraldinsight.com/journals.htm?articleid=1742399

[10] D. Mukherjee. (2009). Impact of celebrity endorsements on brand image. [Online]. Available: http://ssrn.com/abstract=1444814

[11] C. K. Hsu and D. McDonald, "An examination of multiple celebrity endorsers in advertising," Journal of Product and Brand Management, vol. 11, no. 1, pp. 19-28, 2002.

[12] M. J. Baker, Marketing, Macmillan, London, 1981.

[13] K. A. Farrell, G. Kerels, K. W. Monfort, and C. A. McClatchey, "Celebrity performance and endorsemsnt value: The case of Tiger Woods," Managerial Finance, vol. 26, no. 7, pp. 1-15, 2000.

[14] L. R. Kahle and P. M. Homer, "Physical attractiveness of the celebrity endorser: a social adaption perspective," Journal of Consumer Research, vol. 11, no. 4, pp. 954-961, 1985.

[15] B. D. Till and M. Busler, "Matching products with endorsers: Attractiveness versus expertise," Journal of Consumer Marketing, vol. 15 , no. 6 , pp. $576-579,1998$

[16] M. A. Kamins and K. Gupta, "Congruence between spokesperson and product type: A matchup hypothesis perspective," Psychology and Marketing, vol. 11, no. 6, pp. 569-86, 1994.

[17] Merinews. (2006). Famous brands benefit from celebrity endorsement [Online]. Available: http://www.merinews.com

[18] D. Mukherjee. (2009). Impact of celebrity endorsements on brand image. [Online]. Available: http://ssrn.com/abstract=1444814

[19] E. J. MacCarthy, Basic Marketing, Irwin, Holmewood, IL, 1993.
[20] C. Vignaly and B. J. Davies, "The marketing mix redefined and mapped: Introducing the mixmap model," Management Decision, vol. 32, no. 8, pp. 11-16, 1994.

[21] M. J. Bitner, "Evaluating service encounters," Journal of Marketing, p. $54,1990$.

[22] D. Collier, "New marketing mix stresses service," Journal of Business Strategy, vol. 12, no. 2, pp. 42-45, 1991.

[23] C. W. David and F. P. Piercy, Strategic Marketing, $8^{\text {th }}$ ed. vol. 21, pp. 10-11, 21, 378, New York: McGraw Hill Inc, 2009.

[24] P. Kotler, Marketing Insights from A to Z: 80 Concepts Every Manager Needs to Know, John Wiley \& Sons, 2003.

[25] L. Lepisto, "A life span perspective of consumer behavior," Consumer Research, vol. 12, p. 79, 1985.

[26] Kamakura, A. Wagner, and M. Wedel, "Life-style segmentation with tailored interviews," Journal of Marketing Research, vol. 32, no. 3, pp. 308-317, 1995

[27] H. H. Kassarjian and M. J. Shcffet, "Personality and consumer behavior," Perspective in Consumer Behavior, pp. 168-180, 1981.

[28] J. Aaker, "Dimensions of brand personality," Journal of Marketing Research, vol. 34, pp. 347-356, 1997.

[29] W. M. Cameron, Retailing: The Next Generation, London, CEST, 1995.

[30] S. Thechatakerng, The Implementation of Strategic Alliances by Thai Firms, Universitat Autonoma de Barcelona, 2003, p. 2.

[31] R. V. Krejcie and D. W. Morgan, "Determining sample size for research activities," Education and Psychological Measurement, vol. 30, pp. 607-610, 1970 .

[32] W. M. Cameron, Retailing: The Next Generation, London, CEST, 1995.

[33] P. Kotler and G. Armstrong, Modern Marketing, Prentice Hall, 2007.

[34] D. Mukherjee. (2009). Impact of celebrity endorsements on brand image. [Online]. Available: http://ssrn.com/abstract=1444814

[35] J. Nunnally, "Psychometric," Methods, New York: McGraw Hill, 1967.

[36] D. Seno and B. A. Lukas, "The equity effect of product endorsement by celebrities: A conceptual framework from a co-branding perspective," European Journal of Marketing, pp. 121-134, 2007.

[37] Ballester and Espallardo. (2008). Building online brands through brand alliances in internet. [Online]. Available: http://www.emeraldinsight.com/journals.htm?articleid=1742399

[38] G. Birtwistle and L. Shearer, "Consumer perception of five UK fashion retailers," Journal of Fashion Marketing and Management, vol. 5 , no. 1 , pp. $9-18,2001$.

Whachiraporn Boonpradub received her master degree of design in fashion marketing from Northumbria University, New Castle, UK. She works as a part time lecturer at Maejo University. Her research interests include marketing, entrepreneurship, strategic alliances and etc. She is now continuing her study at School of Communication, Journalism and Marketing, Albany Campus, Massey University, Auckland, New Zealand.

Pusanisa Thechatakerng is an assistant professor at the Faculty of Business Administration, Maejo University, Chiangmai, Thailand. She obtained her $\mathrm{PhD}$ and master degrees in entrepreneurship and small business management from Universitat Autònoma de Barcelona, Spain. She was invited as a visiting professor from many countries, for example, Spain, Mexico, Colombia, New Zealand. Her research interests are on entrepreneurship, marketing, management and tourism. 